\title{
FEATURES OF THE PHILOSOPHY PROFESSIONAL METHODS (APPLICABLE AND THEORETICAL ASPECTS)
}

\section{ОСОБЛИВОСТІ МЕТОДИКИ ВИКЛАДАННЯ ФІЛОСОФІї (ПРИКЛАДНИЙ ТА ТЕОРЕТИЧНИЙ АСПЕКТИ)}

\section{Duyk Vadim ${ }^{1}$ \\ Tushko Klavdia ${ }^{2}$}

DOI: dx.doi.org/10.30525/978-9934-571-30-5_28

\begin{abstract}
The article is devoted to the problem of teaching the discipline of philosophy in institutions of higher education. The authors discovered the peculiarities of the methodology of teaching philosophy. Particular attention is devoted to the analysis of such a form of learning as a lecture-essay. In order to confirm the effectiveness of the presented method, the results of the experimental study are presented. The purpose of this article is to analyze the methodology of teaching philosophy in institutions of higher education. The subject of the presented research is the ways of improving the professional training of future specialists on the example of studying the discipline of philosophy. After studying the domestic and foreign experience of methodology of teaching philosophy in institutions of higher education, we have made a choice regarding its optimization, the fixation of the state of formation of professional competence of future specialists of the border department in the process of studying philosophy is constantly carried out. We take into consideration the fact that the subjects of training, which show reasonable optimism about their potential successes, confidence in their future professional activities, are free and open in communicative positions, seek to work on their own self-improvement, set realistic goals, achieve success. In order to confirm the above, at the
\end{abstract}

\footnotetext{
${ }^{1}$ Candidate of Pedagogical Sciences, Associate Professor,

Associate Professor of the Department of Pedagogy and Socio-Economic Disciplines,

National Academy of the State Border Guard Service of Ukraine

named after Bogdan Khmelnitsky, Ukraine

${ }^{2}$ Candidate of Pedagogical Sciences, Associate Professor,

Associate Professor of the Department of Pedagogy and Socio-Economic Disciplines,

National Academy of the State Border Guard Service of Ukraine

named after Bogdan Khmelnitsky, Ukraine
} 
beginning of the first course, among the students of all specialties were conducted questionnaires, interviews, individual interviews, using the method of "unfinished thought" in particular. Thus, by studying the sphere of interests of first-year students, which may affect their professional training and self-realization of the future specialist, we defined the task of our experiment on the effectiveness of the proposed methodology of teaching philosophy in higher education institutions. Therefore, the proposed and applied author's methodology of teaching philosophy allows to determine the levels of formation of professional competence of future specialists, provides wide opportunities for correction of work with the academic group and for individual work with individual students. The features of the methodology of teaching philosophy in institutions of higher education mentioned in the article are author's. Any technique can provide for improvement and transformation. Such a question may be the basis for further research in the presented problem.

\section{1. Вступ}

Сучасний світ змінюється шаленими темпами, гуманізм та толерантність досить часто перестають бути загальнолюдськими цінностями, а сприймаються крізь призму наукових понять, які із реальним життям не мають нічого спільного. Саме на таких історичних етапах кризи моралі та втрати суспільної рівноваги, гуманітарне знання взагалі та філософія зокрема, набували «нового дихання». Тому аналіз філософської спадщини людства стає тим стимулом, який досить часто повертав соціум у систему координат, що визначає людські взаємини, як у значенні вузько особистісному, так і у найширшому розумінні, такими, що відповідають кращим традиціям антропоцентризму та гуманності. Виникає питання: чому присутній такий феномен в певні історичні епохи? Відповідь лежить на поверхні.

Проблемам методики викладання взагалі та філософії і соціально-гуманітарних дисциплін зокрема, присвячені наукові пошуки як вітчизняних, так і зарубіжних вчених. Серед робіт, що досліджують загальні методи викладання навчальних дисциплін, варто відмітити наукові доробки В. Боброва [3], Л. Головко [4], П. Шевчука [8].

Метою представленої статті $є$ аналіз методики викладання філософії у закладах вищої освіти. 


\section{2. Теоретичні основи дослідження}

Філософія, як теоретична форма світогляду, і як раціональний спосіб мислення в своїй основі має запитальний характер, побудову поліваріантних відповідей, наявність когнітивних, етичних та естетичних інструментаріїв, що з необхідністю породжує рефлексію та в кінцевому рахунку повертає людство у вищезгадану систему координат. Споглядання сучасного історичного етапу свідчить, що саме зараз перед людством стоїть непросте питання про його майбутню долю. Діалектична боротьба постіндустріального минулого та інформаційного майбутнього, породила вищезазначену проблему [9]. Тому, саме філософія у вищезгаданому значенні повинна стати фундаментом подолання суперечності між минулим та майбутнім, а методика iii викладання як навчальної дисципліни має сприяти формуванню нового типу, а скоріше типів мислення, що будуть відповідати викликам сьогодення [10]. Ми приймаємо думку американського дослідника М. Ліпмана, який визначає чотири типи мислення, що їх формує вивчення філософії: колективне - міркування з іншими; турботливе - міркування про інших; критичне - прийняття обгрунтованих рішень; креативне - створення нових ідей [19].

Вважаємо за необхідне зазначити, що основну канву представленої наукової публікації, становить опора на наш досвід викладання соціально-гуманітарних дисциплін взагалі та філософії зокрема у закладах вищої освіти різного спрямування.

На нашу думку, викладання вищезгаданих дисциплін повинно здійснюватися не лише на наукових засадах, що в свою чергу передбачає нівелювання усього людського зі сфери пізнання: смаків, емоцій, пристрастей, схильностей. Гуманітарна ж освіта має бути спрямована саме до людської душі, яку позитивна наука не визнає, іiі природа культуроцентрична, а не сайєнтиська. Можна вивчити природничі та точні науки, які є неупередженими, результатом такого вивчення буде формування певних конкретних компетентностей, але не можна в такому самому сенсі «вивчити» філософію чи то культурологію або політологію [13]. Це означає, що за своєю формою соціально-гуманітарне знання є відмінним, воно має на меті не просто засвоєння певної інформації, а формування культури та нової зрілої особистості. В такому контексті методи викладання соціально-гуманітарних дисциплін взагалі та філософії, зокрема, повинні певною мірою відзначатись 
більш творчим (ігровим) началом [14]. У курсанта або студента немає готових рішень, як то при вивченні точних чи природничих наук, а результат отриманих знань та компетентностей є інтерсуб'єктивним за своєю природою, адже філософія у своїх фундаментальних принципах передбачає поліфонію різних, іноді дихотомічних точок зору. Відповідно кінцевий продукт такого засвоєння філософських та соціально-гуманітарних знань теж є інтерсуб' єктивним [18].

Отже, основною та фундаментальною формою у дидактичному конструкті вивчення соціально-гуманітарних дисциплін загалом і філософіï зокрема є лекція, що зумовлено наявністю в ній важливих переваг порівняно з іншими формами навчання. Історичні розвідки пов'язані із вивченням походження та розвитком лекції, як форми навчання засвідчили, що майже на всіх етапах становлення й розвитку вищої освіти саме лекції належала провідна роль у навчальному процесі, хоча іiі місце змінювалося [20]. Провідна роль лекції у навчальному процесі зумовлюється передусім тим, що вона більшою мірою, ніж інші форми навчання, враховує психологічні та гносеологічні особливості процесу навчання і дає змогу реалізувати навчально-виховні цілі [11].

Слід зазначити, що лектор, під час викладання соціально-гуманітарних дисциплін $є$ педагогічним фасилітатором не тільки під час проведення семінарів, але й під час лекції [7]. Ми маємо на увазі те, що лекція не повинна бути переказом матеріалу підручника та констатацією фактів і погоджуємося з думкою Кримського С. про те, що, викладання філософії - це не лише передання певних ідей або ознайомлення 3 результатами наукової творчості лектора, це водночас трансляція особистості, без якої ці ідеї сприймаються як нежиттєві» [16].

Методика підготовки та проведення лекцій є класичною та загальновизнаною, що засвідчив і наш особистий досвід [1]. Отже, можна визначити такі основні вимогами яких повинен дотримуватись викладач під час підготовки до лекції:

- підбір, вивчення та узагальнення здобутків класиків філософської думки з досліджуваної проблеми;

- виділення головного і суттєвого, на що слід акцентувати увагу та під час лекції пропонувати занотувати;

- складання плану робочої лекції;

- вибір методу та стилю викладання конкретної лекції;

- створення мультимедійної презентації. 
Визначені вище вимоги є загальними під час підготовки як до традиційних, так і нетрадиційних лекцій [2]. Крім того, будь-яка лекція має чітко визначену логічну структуру за своїм змістом, а саме:

- послідовність у викладенні проблеми, що заявлена у лекції;

- стислість та чітка визначеність гіпотез, що їх розглядає та висуває лектор;

- доказова та логічна переконливість лектора під час проведення зазначеного виду заняття;

- взаємозв'язок та взаємозумовленість окремих розділів лекції.

Запропонована структура також є традиційною та загальноприйнятою. Слід застерегти молодих колег та особливо ретельно підійти до другого пункту цієї структури. Це пов'язано з тим, що викладач гуманітарій завжди володіє «надлишком інформації» і в цьому контексті на початкових етапах викладацької діяльності, страждає надмірним зловживання часу в процесі лекції на відволікання від «головного». Це в свою чергу стає причиною того, що не завжди лектор встигає викласти весь матеріал лекції.

Перед початком вибору виду лекції, слід пам'ятати, що коли викладач переважно розповідає «про філософію», а курсант або студент прослуховує дану розповідь, ознайомлюється з відповідною термінологією, занотовує іiі, то в такому випадку суть філософії лишається незрозумілою для слухачів. I цілком природно, каже М. Гайдеггер, що, на відміну від інших навчальних предметів, невідвідування занять із філософії може лишитися непомітним для студента, - як, рівнозначно, і сам по собі факт лише відвідування: ані відвідування занять з філософії, ані певною мірою навіть вправне оволодіння в процесі навчання філософською термінологією може бути лише, наголошує мислитель, фактом знаннєвим, а не актом філософування, цим «найістотнішим» виявом буття філософських знань [15, с. 327].

Отже, на нашу думку, традиційні лекції, що не несуть у собі «філософствування» самого лектора, будуть не найкращим методом викладу матеріалу, найефективнішими у викладанні філософії та інших соціально-гуманітарних дисциплін є лекції есе. У педагогічній літературі 3 дидактики, останні досить часто відносять до нетрадиційних, ми можемо з цим погодитись, але у відношенні до інших дисциплін. Для викладання філософії, вряд чи вони є саме нетрадиційними. Лекція есе дає змогу «вирватись» за межі шаблонності, як з погляду іiї змісту, 


\section{Chapter 13. Pedagogical sciences}

так і з огляду на прийоми викладу. Привільно побудована лекція есе $є$ логічно побудованою, думка лектора є бездоганною з позицій формальної логіки (принаймні повинна бути такою), але залишає місце для альтернативи. Така лекція містить у собі всі переваги «сократівської бесіди». Слід зауважити, що викладач філософії завдяки мові не лише повідомляє щось іншому, а поглиблює розуміння і власної свідомості, світовідчуття [5].

В процесі лекції досить ефективним є влаштування так званої сесії «запитань-відповідей» за змістом прослуханого матеріалу. На нашу думку найбільш доречнішими $є$ прості запитання на зразок: «Mи обговорили одне із важливих питань... Що кому найбільше запам'яталося? Що було для Вас новим?». Подібні запитання дають змогу систематизувати прослуханий матеріал та у стислій формі відтворити.

Не зважаючи на зовнішній «консерватизм» філософії, не менш важливим чинником у методиці ії викладання є використання мультимедійних презентацій, особливо під час проведення лекційних занять. Це чудовий сучасний засіб ефективного й результативного навчання: він надзвичайно розширює методичні можливості викладача, бо значно полегшує слухачам процес сприйняття нової інформації - а саме через найвищий рівень наочності. Останні розробки хмарного сервісу Prezi досить суттєво розширюють можливості створення ефективних нелінійних презентацій. Таким чином вирішується два завдання, перше з яких, відхід від лінійного мислення як такого, що руйнує пострадянське світорозуміння, друге створюються ефективні презентації, як супровід лекційних і не тільки занять. Загалом кажучи, переваги мультимедіа-презентації - це: «наочність і зручність». Головним алгоритмом створення навчальної презентації має бути принцип: «Простота, доступність і легкість сприйняття». Досить часто викладачі з невеликим досвідом використання мультимедійного супроводу, перенасичують світлини кольоровим різнобарв'ям, а іноді тезами, які являють собою простий текстовий матеріал. Інколи дехто занадто «роздрібнює» свій виклад на окремі слайди: доходить аж до того, що кожен слайд містить одне окреме речення. Означене призводить до того, що презентація перетворюється на швидку зміну багатьох десятків слайдів, а це відволікає увагу слухача і «збиває його 3 пантелику». Отже, викладаючи матеріал, не слід писати на слайді повного дослівного тексту, який Ви будете оголошувати. На слай- 
дах слід викласти короткі ключові тези. Слід пам'ятати, що слухачі візуально дуже важко сприймають великий масив тексту: натомість слайд з 2-3-х ключових речень сприймається ефективніше і запам'ятовується краще. Слід робити не більше 5-7 рядків тексту на одному слайді. Отже, правильно оволодівши цим інструментом один раз, Ви вже ніколи не зможете обходитися без нього. Але це зовсім не означає, що слід відмовитись від дошки та крейди. Саме під час лекцій з філософії, коли необхідно занотувати ключові положення тієї чи іншої теми, крейда стане ефективним інструмент, що дозволить надати динамічності заняттю.

Не менш важливим елементом методики викладання суспільних дисциплін взагалі та філософії зокрема, є методика проведення семінарських занять. На наше глибоке переконання, саме проведення семінарських 3 філософії та інших соціально-гуманітарних дисциплін, повинно стати трансляцією власного досвіду рефлексивного мислення та спробою курсантів і студентів випробувати власні інтелектуальні здібності. Завданням викладача під час проведення семінарських занять, $є$ формування у тих хто навчається стійкого усвідомлення мудрості як цінності. Саме семінарські заняття повинні стати майданчиком для передачі та пошуку не просто інформації, а смислів. Кожен з учасників семінарських занять повинен відчути себе модератором, підняти якусь проблему, що стосується конкретної теми того чи іншого семінару. Найбільш ефективною моделлю для цього є сократівська бесіда, що дозволяє розвивати й оцінювати своє мислення в порівнянні з мисленням інших. Кожен відповідає на сократичні запитання з їх власних точок зору, відповідно таке обговорення неминуче постає багатовимірним [6].

Семінарське заняття має безпосередній зв'язок із самостійною роботою, яка $є$ фактичним фундаментом для якісного семінару. Об'ємні філософські тексти, принаймні із хрестоматії, повинні бути опрацьовані саме під час самостійної роботи, на їх основі формується власне бачення кожним студентом чи курсантом певної філософської проблеми в різні історичні епохи. Семінарське заняття стає, в такому випадку, поєднанням навчальних і наукових засад у пізнавальній діяльності студентів та курсантів. У процесі підготовки до семінару, вивчення наукової літератури, іiі конспектування, реферування студенти та курсанти оволодівають науковим апаратом, набувають нави- 
чок наукового дослідження. В процесі самого семінарського заняття курсанти та студенти отримують безцінну практику діалогу як методу дослідження, що посилює мислення і навички спілкування, спирається на різні точки зору та підкоряє індивідуальне мислення групі людей.

Під час проведення семінарських занять важливою $є$ есеїстка, тут у пригоді стануть практикуми з філософії [12]. Написання власних есе студентами та курсантами це суб'єктивний, індивідуальний, самостійний простір, де формуються позиції, висловлюються думки, передбачення та демонструється відповідне індивідуалізоване ставлення. Тому головна місія та мета есе - це самостійне бачення студентом чи курсантом проблеми, питання, теми на підставі опрацьованого матеріалу та аргументів, у відповідності до обраного підходу, стилю. Відповідно в процесі написання есе у тих хто навчається формується інструментарій логіки та аргументів, необхідних для процесу критичного мислення.

Ми погоджуємося із думкою сучасного французького дослідником філософії Бреніфє О. про те, що методика викладання важлива, але не менш важливою $є$ методологія мислення. В такому сенсі важливим $\epsilon$ не стільки [17].

Отже, на нашу думку, філософія повинна стати більш практичною та поступово відходити від свого «консерватизму».

\section{3. Методика дослідження}

Вивчивши вітчизняний та зарубіжний досвід методики викладання філософії у закладах вищої освіти, нами зроблено вибір щодо ії оптимізації, постійно здійснюється фіксація стану сформованості професійної компетентності майбутніх фахівців прикордонного відомства в процесі вивчення філософії. Зважаємо на те, що суб'єкти навчання, які проявляють обгрунтований оптимізм з приводу своїх потенційних успіхів, упевненість у своїй майбутній професійній діяльності, $є$ вільними і відкритими у комунікативних позиціях, прагнуть працювати над власним самовдосконаленням, ставлять перед собою реалістичні цілі, досягають відповідних успіхів.

3 метою підтвердження поданого вище, на початку першого курсу серед курсантів усіх спеціальностей були проведені анкетування, опитування, індивідуальні бесіди, використано зокрема методику «незакінченої думки». Таким чином, вивчаючи сферу інтересів кур- 
сантів-першокурсників, що може впливати на їх фахову підготовку та самореалізацію майбутнього фахівця, ми визначали завдання нашого експерименту щодо ефективності представленої методики викладання філософії у закладах вищої освіти.

\section{4. Результати дослідження}

В експериментальному дослідженні було охоплено 370 курсантів першого курсу усіх спеціальностей Національної академії Державної прикордонної служби України імені Богдана Хмельницького. Відповідно до логіки експерименту було сформовано контрольну групу 184 чоловіка та експериментальну - 186 чоловік.

Основними компонентами представленої авторської методики $є$ проведення лекцій-есе з навчальної дисципліни «Філософія».

Результати опитувальника «Визначення мотиващії до пізнавальної діяльності у процесі проведення лекиій-есе з філософії» в групах факультетів Національної академії Державної прикордонної служби України імені Богдана Хмельницького конкретизовано в діаграму «Визначення мотивації до пізнавальної діяльності у процесі проведення лекцій-есе 3 філософії», де вказано відсоткові результати, які надають викладачеві інформацію щодо організації групової і індивідуальної роботи, безпосередньо спрямованої на результат як фахової підготовки, так і підвищення ефективності представленої методики викладання філософії. Мотивація нами обрана як ключовий критерій, оскільки вона відображає рівень інтересів та потреб суб'єктів навчання. Враховуючи вимоги до реалізації педагогічних експериментів нами виокремлено три рівні сформованості мотивації до пізнавальної діяльності: високий, середній, низький. Результати представлено на рисунку 1.

Як видно з рисунку 1, динаміка росту рівня мотивації до пізнавальної діяльності у процесі проведення лекцій-есе з філософії в ЕГ очевидна. КГ мала лише незначні зрушення.

\section{5. Висновки з результатів дослідження}

Отже, запропонована й застосована авторська методика викладання філософії дозволяє визначити рівні сформованості професійної компетентності майбутніх фахівців, дає широкі можливості для корек- 


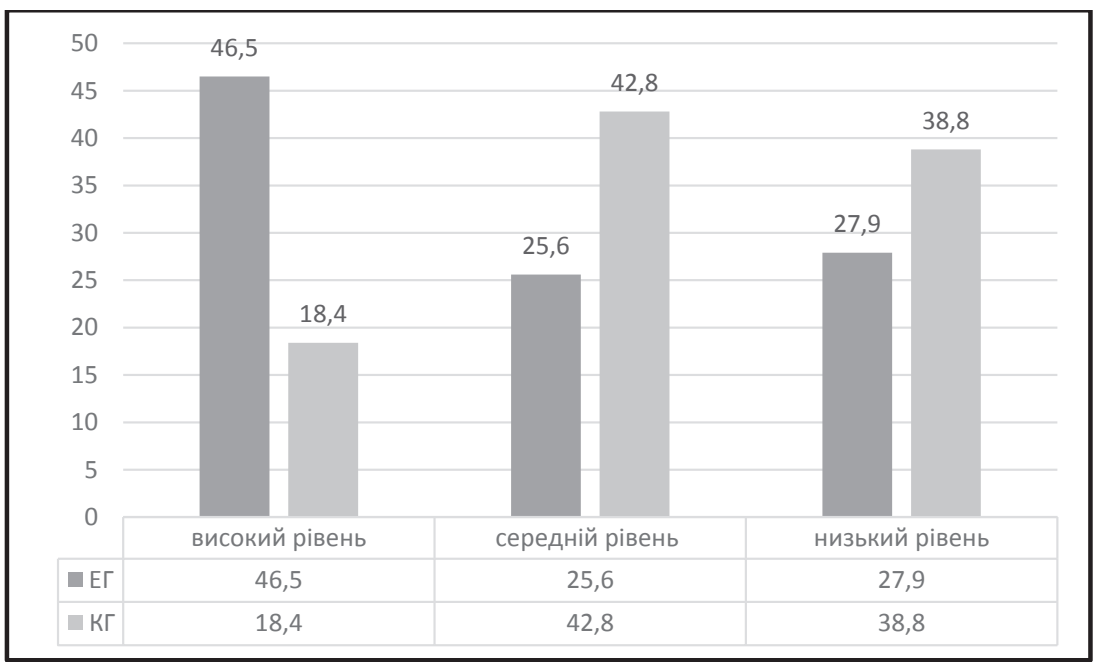

Рис. 1.

ції роботи з академічною групою та для індивідуальної роботи з окремими курсантами.

Зазначені у статті особливості методики викладання філософії у закладах вищої освіти є авторськими. Будь-яка методика може передбачати удосконалення та трансформацію. Таке питання може бути підгрунтям для подальших наукових розвідок у представленій проблемі.

\section{6. Загальні висновки}

Представлені особливості методика викладання філософії у закладах вищої освіти не є остаточними, оскільки сучасні суспільні науки являють собою гнучку систему соціальних, філософських, економічних, політологічних тощо знань, дослідницьких технологій, за допомогою яких вони охоплюють об'єктивну реальність, усі процеси та явища життя, а також його соціальні сфери.

Таким чином, методика викладання філософії вимагає постійного удосконалення свого інструментарію, актуалізації потреб у спеціальній методичній та навчальній літературі, врахування сучасних особливостей освітнього процесу тощо. 


\section{Duyk Vadim, Tushko Klavdia}

\section{Список літератури:}

1. Алексюк А. М., Аюрзанайн А. А., Підласистий П.І. та ін. Організація самостійної роботи студентів в умовах інтенсифікації навчання: навч. посіб. K., 1993. 235 c.

2. Бадмаев Б. Ц. Методика преподавания психологии: учеб.-метод, пособие для преподават. и аспирантов вузов. М.: Гума-нит. изд. центр ВЛАДОС, 1999. $304 \mathrm{c}$.

3. Бобров В. В. Некоторые аспекты опыта преподавания философии в техническом вузе. Сборник материалов Всероссийской конференции «Новые технологии в науке и образовании». Новосибирск, 1998, т. III, с. 185-193.

4. Головко Л. Л. Активізація самостійної роботи студента під час лекційних занять. Освіта і управління. 2002. № 1. С. 15-19.

5. Дьюи Д. Психология и педагогика мышления. М. : Совершенство, 1997. $208 \mathrm{c}$.

6. Жебелев С. А. Сократ: библиографический очерк. М. : Книжный дом «ЛИБРОКОМ», 2009. 192 с.

7. Елсуков А. Н. Методика преподавания социологии в высшей школе: учеб. пособие. Минск: Тетра Системс, 2003. 240 с.

8. Інтерактивні методи навчання: навч. посіб. / за заг. ред. П. Шевчука, П. Фенриха. Щецін: Вид-во WSAP, 2005. 137 с.

9. Кравченко Ю. Інтерв’ю Юлії Кравченко з професором філософії Національного університету Гьонсан (Корея) Джин Ван. Філософія освіти. 2011. № 1-2. С. 292-296.

10. Малахова Ж. Д., Огаренко В. М. Викладання соціології: досвід інноваційних прийомів: навч. пос. К.: Центр учбової літератури, 2008. 280 с.

11. Написання та оформлення курсових, дипломних і магістерських робіт : метод. рекомендації / Укл. С. С. Яремчук. Чернівці : Чернівецький нац. ун-т, $2011.40 \mathrm{c}$.

12. Практическая философия Оскара Бренифье. Журнал современной философии «Сократ». URL: http://socratonline.ru/page/prakticheskaja-filosofijaoskara-brenife

13. Смотрицький Є. Концепція курсу «Філософія для дітей». URL: http://osvita.ua/school/theory/1965/

14. Фрейре Пауло. Педагогіка свободи: етика, демократія і громадянська мужність. К. : Вид. дім «КМ Академія», 2004. 124 с.

15. Хайдеггер М. Время и бытие: Статьи и выступления. М., 1993. 503 с.

16. Шляхтун П. П. Методика викладання соціально-гуманітарних дисциплін: навч. посіб. К.: ВЦ «Академія», 2011. 224 с.

17. Hatice Ahsen Utku. Oscar Brenifier philosophizes on life with questions. URL: http://www.todayszaman.com/news-197274-oscar-brenifier-philosophizeson-life-with-questions.html

18. Jinju Conference Declaration for Philosophy Education by the 15th CIPIC Conference (2011). URL: http://pepenap.wordpress.com/declaration

19. Lipman Mattew (2003). Thinking in education. UK : Cambridge University Press, $304 \mathrm{p}$.

20. Sharp A. M. (1991). The Community of Inquiry: Education for Democracy. Thinking. Vol. 9. P. 31-37. 


\section{References:}

1. Aleksiuk A. M., Aiurzanain A. A. (1993). Pidlasystyi P. I. ta in. Orhanizatsiia samostiinoi roboty studentiv $\mathrm{v}$ umovakh intensyfikatsii navchannia: navch. posib. [Organization of independent work of students in conditions of intensification of training] 235 p. (in Ukrainian).

2. Badmaev B. Ts. (1999). Metodyka prepodavanyya psykholohyy: Ucheb.metod, posobye dlya prepodavat. y aspyrantov vuzov. [Methods of teaching psychology] M.: Huma-nyt. yzd. tsentr VLADOS, 304 p. (in Russian).

3. Bobrov V. V. (1998). Nekotoryye aspekty opyta prepodavaniya filosofii v tekhnicheskom vuze [Some aspects of the experience of teaching philosophy in a technical university]. Sbornik materialov Vserossiyskoy konferentsii "Novyye tekhnologii v nauke i obrazovanii”. Novosibirsk, t. III, pp. 185-193.

4. Holovko L. L. (2002). Aktyvizatsiia samostiinoi roboty studenta pid chas lektsiinykh zaniat.[Activation of student's independent work during lectures] Osvita i upravlinnia. 2002. № 1. pp. 15-19.

5. Dyui D. (1997). Psikhologiya i pedagogika myshleniya.[Psychology and pedagogy of thinking] M. : Sovershenstvo. 208 s. (in Russian).

6. Zhebelev S. A. (2009). Sokrat: bibliograficheskiy ocherk [Socrates: Bibliography]. M. : Knizhnyy dom "LIBROKOM". 192 p.(in Russian).

7. Elsukov A. N. (2003). Metodika prepodavaniya sotsiologii v vysshey shkole: ucheb. posobiye. [Methodology of teaching sociology in higher education: Textbook] Minsk: Tetra Sistems. 240 p. (in Russian).

8. Interaktyvni metody navchannia: navch. posib. / za zah. red. P. Shevchuka, P. Fenrykha. (2005). 137 p.

9. Kravchenko Yu. (2011). Interviu Yulii Kravchenko z profesorom filosofii Natsionalnoho universytetu Honsan (Koreia) Dzhyn Van. [Interview with Julia Kravchenko with Professor of Philosophy at the National University of Gyosn (Korea), Jean Wang] Filosofiia osvity. № 1-2, pp. 292-296.

10. Malakhova Zh. D., Oharenko V. M. (2008). Vykladannia sotsiolohii: dosvid innovatsiinykh pryiomiv: navch. pos. [Teaching sociology: the experience of innovative techniques] $280 \mathrm{~s}$. (in Ukrainian).

11. Napysannia ta oformlennia kursovykh, dyplomnykh i mahisterskykh robit : metod. rekomendatsii [Writing and registration of course, diploma and master's works: method.recommendations] / Ukl. S. S. Yaremchuk. Chernivtsi. (2011). 40 s.

12. Prakticheskaya filosofiya Oskara Brenifye. Zhurnal sovremennoy filosofii "Sokrat". URL: http://socratonline.ru/page/prakticheskaja-filosofija-oskara-brenife

13. Smotrytskyi Ye. (1965). Kontseptsiia kursu "Filosofiia dlia ditei". [Concept of the course "Philosophy for Children"] URL: http://osvita.ua/school/theory/1965/

14. Freire Paulo. (2004). Pedahohika svobody: etyka, demokratiia i hromadianska muzhnist. [Pedagogy of freedom: ethics, democracy and civic courage]. 124 p. (in Ukrainian).

15. Khaydegger M. (1993). Vremya i bytiye: Stati i vystupleniya. [Time and Being: Articles and speeches]. M. 503 p. (in Russian).

16. Shliakhtun P. P. (2011). Metodyka vykladannia sotsialno-humanitarnykh dystsyplin: navch. posib.[Methodology of Teaching of Social and Humanitarian Disciplines: Teaching]. 224 p. (in Ukrainian). 


\section{Duyk Vadim, Tushko Klavdia}

17. Hatice Ahsen Utku. Oscar Brenifier philosophizes on life with questions. URL: http://www.todayszaman.com/news-197274-oscar-brenifier-philosophizeson-life-with-questions.html

18. Jinju Conference Declaration for Philosophy Education by the 15th CIPIC Conference (2011). URL: http://pepenap.wordpress.com/declaration

19. Lipman Mattew. (2003). Thinking in education. UK: Cambridge University Press. 304 p.

20. Sharp A. M. (1991). The Community of Inquiry: Education for Democracy. Thinking. Vol. 9. P. 31-37. 